\title{
Cytoplasm Presence of Less than or Equal to Twenty Five Percent
}

National Cancer Institute

\section{Source}

National Cancer Institute. Cytoplasm Presence of Less than or Equal to Twenty Five

Percent. NCl Thesaurus. Code C104013.

A morphologic finding indicating the presence of less than or equal to twenty five percent

of clear or vacuolated cells that resemble the normal zona fasciculata in adrenocortical tumors. 